Cornell Law Library Scholarship@Cornell Law: A Digital Repository

Fall 2002

\title{
Comparative Readings of Roscoe Pound's Jurisprudence
}

Mitchel de S.-O.-l'E. Lasser

Cornell LawSchool,ml355@cornell.edu

Follow this and additional works at: http://scholarship.law.cornell.edu/facpub

Part of the Comparative and Foreign Law Commons, Jurisprudence Commons, and the Legal Education Commons

\section{Recommended Citation}

Lasser, Mitchel de S.-O.-l'E., "Comparative Readings of Roscoe Pound's Jurisprudence" (2002). Cornell Law Faculty Publications. Paper 738.

http://scholarship.law.cornell.edu/facpub/738 
MITCHEL LASSER

\section{Comparative Readings of Roscoe Pound's Jurisprudence}

Roscoe Pound remains a particularly enigmatic character in the history of American jurisprudence. On the one hand, he is the muchbeloved young lion whose early and enthusiastic support of sociological jurisprudence marked the death-knell of Nineteenth Century formalism or "mechanical jurisprudence." On the other hand, he is the stubborn and authoritarian old dean of the Harvard Law School whose sour reception of, and even hostility towards, legal realism represented an oddly reactionary resistance to the logical development of his own early work.

What is largely forgotten, however, is the seminal role that Pound played in the history of American comparative law. Despite his stunningly long and prominent academic career, and despite the centrality of comparative law to his teaching and scholarly agendas, Roscoe Pound's direct impact on contemporary American comparative law can best be described as non-existent. Pound taught law for over fifty years, served as Dean of the Harvard Law School for over twenty, and was still actively publishing until $1960 .{ }^{1}$ From the very beginning of his academic career, Pound was deeply interested in, taught, researched, and wrote about comparative law. His initial teaching load at the law school of the University of Nebraska in 1899, for example, consisted of courses in Analytical Jurisprudence, Historical Jurisprudence, Roman Law, Comparative Law, and History of English Law. ${ }^{2}$ In the 1950 's, near the end of his career, he even served seven years as the President of the Académie Internationale de Droit Comparé. ${ }^{3}$ Nonetheless, Roscoe Pound has been all but forgotten by contemporary American comparativists, qualifying him perhaps as American comparative law's most famous unknown practitioner.

Mitchel Lasser is Samuel D. Thurman Professor of Law at the University of Utah's S.J. Quinney College of Law. Special thanks to Annelise Riles and Lee Teitelbaum.

1. Pound began his career at the University of Nebraska in 1899. He then taught at Northwestern and the University of Chicago before moving to the Harvard Law School, where he taught for some forty years and served twenty years as its Dean. David Wigdor, Roscoe Pound: Philosopher of Law (1974).

2. Paul Sayre, The Life Of Roscoe Pound 143 (1948).

3. Roscoe Pound, 1 Jurisprudence, at iv (1959). 
Why, then, would one study his comparative work? The answer is that it might well possess significant current potential for the discipline of American comparative law. The source of this potential lies in the particular history of the discipline, which has been dominated by realist-inspired methodologies for over thirty years. I believe that it is important to recognize and account for the interaction between the realist slants of both American comparative law and American legal education. This interaction makes it all too easy for American students of comparative law (including seasoned academics) to read Dawson, Merryman and even myself in a way that simply reflects and reinforces their parochially realist assumptions, thereby gaining little access to the civilian systems they study.

Modern American analyses of the French civil judicial system provide an excellent example. Dawson and Merryman produced absolutely groundbreaking, realist-inspired analyses and critiques of the French judicial system. ${ }^{4}$ Their great advance was to refuse to accept that French judges were merely passive and mechanical applicators of the Civil Code, as the official pronouncements of the French legal system would lead one to believe. Working on the realist assumption that no code could be perfect, they came to understand that French judges had in fact played an important normative role in the French legal system. As good realists, however, Dawson and Merryman criticized the French system's formalist facade for driving such normative judgments underground, a process that they believed cut French judges off not only from public view, but also from each other, resulting not only in hidden, but also in individual and ad hoc responses to changing social, economic and institutional policy needs. ${ }^{5}$ When, furthermore, my own research at the Cour de cassation revealed that French judges, in an institutionalized discursive sphere hidden within their judicial system, engaged in just the kind of reasoned, coherent, responsible and institutional policy debates that Dawson and Merryman claimed they did not, ${ }^{6}$ American students of comparative law were therefore faced with a radically different picture of French - and by extension civilian - legality than had been available before the publication of Dawson's and Merryman's seminal works.

An unforeseen problem emerged however in the form of certain responses that I periodically received from students who had read the analyses of Dawson, Merryman and myself. These responses, often distressingly blasé, would run along the following lines: "Of course French judges make law. What else could they do?," or "See, we are all the same. Their judges are just like ours! It's all policy. ..." The

4. See John Dawson, The Oracles Of The Law (1968); John Henry Merryman, The Civil Law Tradition (1969).

5. See Lasser, "Judicial (Self-)Portraits: Judicial Discourse in the French Legal System," 104 Yale L.J. 1325, 1329-33 (1994).

6. See id. at 1343-1410. 
more I have encountered such responses, the more uncomfortable I have become with them. They demonstrate the extent to which American legal education often consists of the reductive internalization of certain American legal realist arguments, such as "If judges decide cases, they must necessarily be making law," or "The law is what the judge says it is," or perhaps, "Law is what the judge does in fact." These arguments are often ingested as assumptions with little or no awareness that they might only reflect a particular theory about law that emerged in the United States at a particular historical moment, or that they might be related to the particular role of the American common law judge, or that they might simply be arguments about how best to think about the law for certain purposes. In short, in contemporary American law schools, students tend to take it as an obvious fact that the law is what the judge does in fact. To them, this definition of law simply represents what the law is, as an essential matter.

The resulting problem, of course, is that this American realist definition of law, when applied uncritically to a civilian - and especially to the French - legal system, leaves little or no possibility of encountering that system. It simply collapses the civilian system into the American perspective. The student is not open to other ways of understanding what law is. Worse yet, this realist perspective, applied to the research of Dawson, Merryman and myself, simply appears to reinforce this parochially American understanding of law. In the end, it seems, the law is what (policy) the judge does in fact. By a play of mirrors, the American student of comparative law has been exposed to nothing more than a reflection of what (s)he "knew" in the first place.

Given my desire to come to terms with the effects that the realist legacy has had on the discipline of American comparative law, it is not by accident that I have chosen to analyze the comparative work of Roscoe Pound. As his famous exchange with Karl Llewellyn made abundantly clear, Pound was no friend of American legal realism. ${ }^{7}$ Pound's work might therefore offer an alternative methodology to that which has dominated American comparative law for at least the last thirty years. In particular, his work might offer a model of how to escape the typical American post-realist prism which tends, almost as a matter of first principle, to define law in the Holmes/Llewellyn manner as "what the courts do in fact." 8 Pound's comparative work, in other words, may offer a methodological alternative to American comparative law's tendency to approach law in a judge-centered man-

7. See Pound, "The Call for a Realist Jurisprudence," 44 Harv. L. Rev. 706 (1931); Llewellyn, "Some Realism About Realism - Responding to Dean Pound," 44 Harv. L. Rev. 1237 (1931).

8. See Holmes, "The Path of the Law," 10 Harv. L. Rev. 460-61 (1897), Karl Llewellyn, The Bramble Bush 3 (1930). 
ner, a tendency that obliterates precisely the locus of the most basic differences between American and Continental European legal ideologies.

This analysis proceeds as follows. Part II briefly summarizes the basic characteristics of Roscoe Pound's comparative work. In order to keep the summary manageable, I will not seriously examine Pound's myriad addresses, law review articles, or short monographs. Instead, I will limit my consideration primarily to Pound's massive five-volume treatise, Jurisprudence. ${ }^{9}$ This treatise, published in 1959, represents the culmination of Pound's life-long jurisprudential career. It offers the great advantage of reiterating - some might say rehashing ${ }^{10}$ - sixty years' worth of Pound's work, and therefore offers a convenient point of access to Pound's prolific writings. Furthermore, published as it was in 1959, the treatise offers not only Pound's primary work, but also that work as revisited and revised by Pound over the years. ${ }^{11}$ In particular, the late publication date means that Pound was able to position his own work relative to realist and postrealist writings. Finally, as Jurisprudence was published in 1959, it represents a surprisingly recent comparative law piece.

Part III offers what I consider to be a "generous" reading of Pound's comparative work. That is, it proposes a reading that highlights the most nuanced and suggestive elements of Pound's comparative analyses. This generous reading focuses on three fundamental facets of Pound's work. First, it acknowledges Pound's remarkably cosmopolitan erudition in the substantive law and legal theory of both foreign and domestic origin, and considers the effects of this erudition on his comparative analysis. Second, and deeply related to the first, the generous reading stresses the extent to which Pound's comparative work escapes a purely common-law-centric perspective on his objects of analysis. Finally, this reading suggests that Pound's cosmopolitan perspective produces promising comparative methodologies by deploying categories that are not clearly parochial in origin. That is, by deploying non-common-law-centric categories, Pound's comparative work can offer nuanced, sensitive, and historically and geographically contingent comparative analyses.

Part IV, however, offers what I consider to be a "severe" reading of Pound's comparative work. That is, it proposes a reading that highlights the most problematic elements of Pound's comparative analyses. This severe reading also focuses on three fundamental aspects of Pound's work. First, it acknowledges the crude model of legal evolution that permeates Pound's jurisprudence. Second, and deeply re-

9. Roscoe Pound, Jurisprudence (1959) [hereinafter "Jurisprudence"].

10. See Wigdor, supra n. 1, at 280 ("[I]n 1959 the long-awaited Jurisprudence appeared in five magnificent volumes. It was, regrettably, an anticlimax, for it summarized his work without synthesizing it.")

11. See 1 Jurisprudence, at xi-xii. 
lated to the first, the severe reading stresses not only the extent to which Pound's crudely evolutionary model is teleological in nature, but also how the telos of his narrative still turns out to be, perhaps not terribly surprisingly, quite clearly common-law-centric. Finally, this reading suggests that Pound deploys his comparative legal analysis for parochial jurisprudential ends. That is, this reading stresses the extent to which Pound's comparative work dovetails with, and ultimately takes a back-seat to, both his anti-mechanical and his anti-realist jurisprudential agendas.

Part V offers conclusions. In particular, it addresses in greater detail why I found it necessary to offer two separate and quite different readings of Pound's text. It suggests that the specificity of Pound's comparative work may well lie in its remarkable rhetorical ability to sustain widely divergent readings. It argues, therefore, that a synthesis of the "generous" and "severe" readings would not do justice to the rhetorical complexity, nuance and tension that characterizes Pound's comparative work.

Finally, Part V also suggests that Pound's text can be read in very different ways depending not only on which pages of Pound's text one happens to read or to stress, but also on the reader's own projects and commitments. The production of two distinct readings therefore stresses the situated character of the reader's reading, and, by analogy, of the comparativist's analyses. In addressing Pound's comparative work, the comparativist engages in prototypically comparative analysis.

\section{A Brief Introduction to Pound's Comparative Analysis}

Roscoe Pound's general jurisprudence offers a double methodological bent. First, it is explicitly comparative. As Pound states as early as 1903 , jurisprudence "might be called: the comparative anatomy of developed systems of law."12 Pound therefore opens Jurisprudence with a call to comparativism. The first words of the Preface state:

Since Austin, books in English on jurisprudence have been written primarily for students upon the study of law or for their teachers. But with the passing of the localism characteristic of the Anglo-American lawyer of the past generation, growing cultivation of comparative law and rising expectations of ultimate achievement of a law of the world, exposition of the science of law should have a wider scope. ${ }^{13}$

Second, his general jurisprudence is pervasively historical. Three paragraphs later, Pound therefore states that his analysis "is not to

12. Roscoe Pound, Outlines of Lectures on Jurisprudence 4 (1903).

13. 1 Jurisprudence, at vii. 
be set forth dogmatically in abstract propositions but will appear in the setting forth of the actual historical and doctrinal or legislative developments of the law as a whole and of special fields of the law."14

Pound deploys his comparative historical methodology to advance two fundamental theses. First, Pound claims that western legal history has progressed through a series of "stages" of development. ${ }^{15} \mathrm{He}$ calls these stages "primitive law," "the strict law," "equity and natural law," "the maturity of law," and "the socialization of law." $16 \mathrm{He}$ also suggests an impending stage in a section appropriately entitled, "What of a Next Stage - A Law of the World?"17

Pound defines and constitutes these five (or perhaps six) "stages of development" according to the "end of law as developed in legal precepts and doctrines." 18 That is, he divides Western legal history into stages according to what theory of justice, or what "purpose of social control and of the legal order," motivated and characterized legal systems of a given period. ${ }^{19}$ Pound then catalogues the means by which legal systems of a given stage have attempted to promote the stage's end, and the characteristic traits of a legal system in that stage. He then summarizes of his stage analysis in charts such as the following ${ }^{20}$ :

\begin{tabular}{|l|l|l|l|l|}
\hline & Primitive law & The strict law & $\begin{array}{l}\text { Equity and } \\
\text { natural law }\end{array}$ & $\begin{array}{l}\text { The maturity } \\
\text { of law }\end{array}$ \\
\hline End & Public Peace & Security & $\begin{array}{l}\text { Ethical } \\
\text { conduct: } \\
\text { conformity to } \\
\text { good morals }\end{array}$ & $\begin{array}{l}\text { Equity of } \\
\text { opportunity; } \\
\text { security of } \\
\text { acquisitions }\end{array}$ \\
\hline Means & Composition & Legal remedy & $\begin{array}{l}\text { Enforcement } \\
\text { of duties }\end{array}$ & $\begin{array}{l}\text { Maintenance } \\
\text { of rights }\end{array}$ \\
\hline $\begin{array}{c}\text { Permanent } \\
\text { contribution } \\
5\end{array}$ & $\begin{array}{l}\text { Peaceable } \\
\text { ordering of } \\
\text { society }\end{array}$ & $\begin{array}{l}\text { Certainty and } \\
\text { uniformity } \\
\text { reached by } \\
\text { rule and form }\end{array}$ & $\begin{array}{l}\text { Good faith } \\
\text { and moral } \\
\text { conduct, } \\
\text { attained by } \\
\text { reason }\end{array}$ & $\begin{array}{l}\text { Thorough } \\
\text { working out } \\
\text { of the idea of } \\
\text { individual } \\
\text { rights }\end{array}$ \\
\hline
\end{tabular}

Pound could hardly make his historical analysis more clear and concise.

Pound's stage by stage historical analysis possesses two essential traits. First, it offers a unified history of the stages of development of

14. Id. at viii.

15. Id. at 367 .

16. Id. at 361 .

17. Id. at 457.

18. See id. at 363-66.

19. See id.

20. Id. at 428. 
Western legal systems. When Pound describes any given historical stage, he therefore refers freely to a large number of legal systems, from that of classical Rome, to those of France, Germany, England, or the United States.

Second, Pound's unified historical analysis is not strictly temporal. Thus, for example, when Pound describes the stage of "equity and natural law," he grounds the discussion by referring to several specific legal systems. He states:

A stage of liberalization, which may be called the stage of equity and natural law, succeeds the strict law. In Roman law, this stage is represented by the period from the development of praetorian law to the monarchy (Diocletian and Constantine) - especially the classical period from Augustus to the end of the first quarter of the third century. In English law it is represented by the rise of the Court of Chancery and the development of equity ....- roughly, the seventeenth and eighteenth centuries. In the law of Continental Europe it is represented by the period of the law-of-nature school, that is, again, the seventeenth and eighteenth centuries. ${ }^{21}$

This passage demonstrates both the unified and somewhat atemporal traits of Pound's historical analysis. Under the same rubric of the "equity and natural law" stage of legal development, Pound refers to legal systems separated by some fifteen hundred years.

This non-linear quality to Pound's comparative historical methodology leads to the second of Pound's two fundamental theses. In contrast to his first thesis, namely, that western legal history has progressed through a series of discrete stages of development, Pound also offers a rather cyclical theory of legal history.

Pound's cyclical theory rests on his initial distinction between "the two elements of a legal system." 22 He states: "A developed body of legal precepts is made of two elements, an enacted or imperative and a traditional or habitual element." 23 The traditional element "is developed by judicial experience and juristic science." 24 It "rests at first upon the usage and practice of tribunals or the usage and customary modes of advising litigants on the part of those upon whom tribunals rely for guidance. Later, under the influence of teaching and of philosophy it comes to rest upon juristic science and the habitual modes of thought of a learned profession."25 The imperative element, on the other hand, is the body of legislation, statutes or codes

21. Id. at 406-07.

22. 2 Jurisprudence at 9.

23. Id.

24. Id. at 12 .

25. Id. at 13 . 
enacted by the expressed will of the lawmaker under authority of state power. ${ }^{26}$

Pound argues not only that at any given time, "[a] developed body of legal precepts is made of [the] two elements," 27 but also that "[t]here is a constant shifting back and forth between these elements." 28 This "shifting back and forth" produces a cyclical quality to legal history over time. Pound states:

In time, legislation becomes absorbed in the traditional element of the legal system, and the enacted rule becomes a traditional principle or the theoretical basis of a traditional doctrine. There is a gradual transformation of the first element into the second. ${ }^{29}$

On the other hand, as the traditional element is developed by judicial experience and juristic science, and its principles are worked out into detailed rules, these rules come to be given imperative form by legislation. Thus there is a gradual transformation of the traditional into the imperative. ${ }^{30}$

Over the course of its history, therefore, a legal system gradually but perpetually seesaws between its traditional and imperative elements.

Roscoe Pound's Jurisprudence, in short, offers two very different theories of legal history in the comparative context. The first is linear: It posits that legal systems progress through a series of particular developmental stages. The second is cyclical: It posits not only the synchronic coexistence of the imperative and traditional elements in any given legal system at any given time, but also the diachronic seesawing between the two elements in any given legal system over time.

\section{The Generous Reading}

The coexistence of Pound's linear and cyclical theories makes it very difficult to offer a single interpretation and assessment of Pound's comparative work. If one adds to this theoretical complexity Pound's fantastically exhaustive presentation, among many other things, of the history of western jurisprudence, Jurisprudence - all 2500-plus pages of it - offers more than enough grist to the interpretive mill of any supporter or detractor. This Part therefore begins my analysis by offering what I consider to be a "generous" reading of Pound's comparative work. It proposes a reading that highlights the

26. Id. at $10-14$.

27. Id. at 9 .

28. Id. at 10 .

29. Id.

30. Id. at 12 . 
most nuanced and suggestive elements of Pound's comparative analyses.

Pound's intimidatingly cosmopolitan erudition represents perhaps the most immediately obvious attribute of his treatise. This erudition covers not only American and English law, but also routinely refers at length to Roman, French and German sources, and not infrequently to several others. Furthermore, his erudition spans the works of several thousand years, as Pound does not merely present snapshots of typical American, English, Roman, French and German sources, but also analyzes the historical development of those sources through assorted historical periods. ${ }^{31}$ In short, Pound certainly knew how to drop a footnote! ${ }^{32}$

The following footnote provides a typical example of the breadth and specificity of Pound's cosmopolitan erudition. Under the heading of "The Revival of Natural Law," Pound offers the following cites:

Charmont, La renaissance du droit naturel (1910) - translated in part in Modern French Legal Philosophy (7 Modern Legal Philosophy Series) $\S \S 43-103$, of which $\S \S 78-103$ are important in the present connection; Haines, The Revival of Natural Concepts ch. 10 (1930); Beudant, Le droit individuel et l'état (1891, 3d. ed. 1920); 2 Gény, Science et technique en droit privé positif (1914-1924) $\$ \S 134-140,177$; Demogue, Notions fondamentales du droit privé (1911) 21-22; Leroy, Le temps présent et l'idée du droit social (1932) Archives de philosophie du droit et de sociologie juridique, 215-228; Gurvitch, Le temps présent et l'idée du droit social (1931); Jung, Das problem des natürlichen Rechts (1912); Moór, Das Problem des Naturrechts $(1934,1935) 28$ Archiv für Rechts und Sozial Philosophie, 325, 543; Goldschmidt, Die heutigen Strömungen in der Rechtswissenschaft (1936) 10 Revue internationale de la théorie de droit, 300, 302.33

This profoundly cosmopolitan footnote refers without distinction and without translation - to academic works originating from several different countries.

The breadth of Pound's cosmopolitan erudition surfaces over and over again in his treatise. His citations, furthermore, are not limited to such standard materials as those concerning "The Revival of Natural Law." Thus, under the heading of "The Economic Realists," Pound refers to the decidedly less mainstream work of "the anarchist indi-

31. See, e.g., 1 Jurisprudence at 25-547.

32. Lee Teitelbaum has stressed to me the importance of Pound's work as an avenue for the American reception of foreign ideas: Pound's footnotes represented an important educational resource for American jurists interested, inter alia, in European sociological work.

33. Id. at 178, n. 122 . 
vidualists or philosophical anarchists." He then drops the following footnote:

Proudhon, Qu'est-ce-que la propriété? (1840); id. Idée générale de la révolution au dix-neuvième siècle (1851); id. De la révolution et dans l'église (1858); Stirner, Der Einzige und sein Eigenthum (1845, English trans. as The Ego and His Own, 1907); Grace, La société fututre (7 ed. 1895). See Basch, L'individualisme anarchiste: Max Stirner (1904). ${ }^{34}$

Pound's academic citations are so thorough that he refers here to no less than three Proudhon texts!

Furthermore, Pound's cosmopolitan erudition is not limited, furthermore, to academic theory. Thus, for example, when Pound addresses the "limitations on the power of the creditor" that he considers characteristic of the "socialization of law," 35 he discusses homestead exemptions and inserts the following footnote:

Thomson, Homesteads and Exemptions (1878) §§ 40, 379; Bureau, Le Homstead ou l'insaisissabilité de la petite propriété foncière (1895). In Germany, claims for wages, claims under the laws as to compulsory insurance and claims for maintenance are exempt from seizure. Code of Civil Procedure, § 850. See also National Labor Relations Board v. Sunshine Mining Co., 125 F.2d 757, 761, 765 (C.C.A.9th, 1942) preventing prosecution of the claims of dependent wives, divorced wives, and creditors of laborers to whom back pay had been awarded; Woodbridge, Wage Earners' Receiverships (1940) 23 J. Am. Jud. Soc. 242. ${ }^{36}$

This passage offers a truly remarkable hodgepodge of references to more and less current, foreign and domestic, substantive law. Pound makes little formal distinction between these references, choosing instead to group them together in a single, almost pan-national and pan-historical footnote.

The depth and breadth of Pound's multinational and trans-historical field of substantive and theoretical references suggest that Pound might possess a remarkably panoramic vista for large-scale comparative analysis. After all, who else can make the sort of wideranging connections and comparisons that we have been observing and that Pound demonstrates on almost every page of his treatise? Furthermore, Pound's field of references also suggests the possibility of engaging in very precise and subtle understandings of the local. Pound, it seems, might actually know something about German creditor/debtor law. . .

34. Id. at 523, n. 147 .

35. Id. at 442 .

36. Id. at 444, n. 41. 
Of course, Pound's display of erudition is not entirely seamless. The treatise does contain passages that might well shake the contemporary reader's faith in Pound's data set as well as in his methodology and analysis. For example, when he discusses how, "in Oriental justice, the will element greatly preponderates," 37 Pound refers to the Arabian Nights (!) to advance his thesis. ${ }^{38}$ Even Pound's ensuing citation to Wigmore is far from problematic: the reference is to Wigmore's work on "Old Japan." ${ }^{39}$ As a result, Pound's "Orient" happily encompasses not only the fictitious (the Arabian Nights) and the apparently non-fictitious (Wigmore), but also spans all the way from "Arabia" to Japan. ${ }^{40}$ In fact, Pound even refers to the justice of the Amir of Afghanistan as described by Rudyard Kipling.41

The breadth and quality of Pound's references, in other words, can sometimes be open to debate. It should be noted, however, that even in the context of such a dubious analysis of "the Orient," Pound can disarm the critic, if only partially. As soon as he refers to Kipling's description, Pound produces another comparative example. He states:

Compare Kipling's story of the Amir of Afghanistan: "The king may be pleased and praise the speaker to honor for that very bluntness of speech which three minutes later brings a too imitative petitioner to the edge of the ever-ready blade." This is not confined to Oriental justice, as is shown by imposition of the death penalty by California juries. Going over the cases in Duke, Celebrated Criminal Cases in America, it appears that the general tendency was in the case of picturesque murder to impose imprisonment for life; in case of murder without the picturesque element, hanging. ${ }^{42}$

Thus even in this orientalizing context, Pound produces a cosmopolitan comparative analysis that immediately implicates "the West" (even if only the "Wild West").

Pound's academic cosmopolitanism, as manifested in the remarkably trans-historical and trans-national nature of his references, therefore acutely affects his comparative jurisprudence. Even when his analysis stands on its least sure footing (as in the orientalizing example above), Pound nonetheless succeeds in maintaining a comparative perspective that does not entirely revolve around the com-

37. 2 Jurisprudence, at 355.

38. Id. at $355-56$.

39. See id. at 356 , n. 14, citing Wigmore, "The Legal System of Old Japan," 4 Green Bag 403 (1892). For a fascinating analysis of Wigmore's comparative scholarship, see Annelise Riles, "Wigmore's Treasure Box: Comparative Law in the Era of Information," 40 Harv. Int'l L.J. 221 (1999).

40. This is to say nothing about the time frame involved in the comparison.

41. Id. at $355-56$, n. 13 , citing Kipling, "The Amir's Homily," in In Black and White 204 (Outward Bound ed.).

42. Id. (citations omitted). 
mon law. Not only does Pound routinely draw explicit parallels between, for example, English, American and Roman law, ${ }^{43}$ but he happily groups together "Oriental" and American examples. ${ }^{44}$ Pound's cosmopolitan perspective therefore produces a surprisingly unified analysis of comparative jurisprudential history.

Furthermore, Pound's extensive erudition not only permits him to construct this rather cosmopolitan legal history, but it also affects the choice of methodologies used to construct that history. Perhaps the clearest evidence of this methodological carry-over is provided by the very structure of Pound's treatise. For example, Part I of Jurisprudence - itself entitled "Jurisprudence" - consists of a historical presentation of western legal theory. ${ }^{45}$ This presentation closely resembles legal history as it is typically constructed by Continental European academics. That is, instead of offering a history of "great cases," it proposes a history of legal theory, of jurisprudence. The treatise presents this history, in prototypically civilian fashion, as a history of the rise and fall of successive (or at times rival) "schools" of jurists. This approach demonstrates the extent to which Pound's learning allows his treatise to move away from judge-centered, American common law perspectives.

Distancing his comparative analyses from such American judgecentered perspectives, Pound refuses to adopt a methodology oriented primarily towards the judicial process. Pound states:

Realist theories. More than one reason led American realists to define law in terms of the judicial process. One is the central position of the court in the Anglo-American legal system and the concrete character of a legal precept in that system, as a product of the courts rather than of the universities. ... Certainly the judicial process (to which today we must add the administrative process) is something of which a theory of the subject matter of jurisprudence must take account. But in order that account be taken of it, it does not become necessary to call it law. ${ }^{46}$

In this crucial passage, Pound refuses to adopt a parochial methodology that he associates explicitly with Anglo-American common law systems.

Needless to say, by refusing such a judge-centered or "judicial process" methodology, Pound turns his back on perhaps the most fundamental orientation of twentieth century American jurisprudence. By doing so, he refuses to define law as what "the courts do in fact" 47

43. See, e.g., 1 Jurisprudence, at 416.

44. See 2 Jurisprudence, at 355-56.

45. See 1 Jurisprudence, at 7-358.

46. 2 Jurisprudence, at 83-84.

47. Holmes, supra n. 8, at 460-61. 
or as what "officials do about disputes." 48 That is, he rejects the methodological perspective that begins most notably with Holmes and continues most vocally with Llewellyn. ${ }^{49}$

Pound appears to have been extremely conscious of the methodological danger of relying on such parochial conceptions. He argues forcefully:

This [Anglo-American] emphasis on the role played by the court in determining what is law would not be likely except under the common-law legal system where our doctrine of case law and precedent makes the court the all important force in lawmaking. The rise of decided cases as a form of law on the Continent may in time result there also in looking at the court rather than at the legislature. Perhaps nothing could make more clear the extent to which juristic theory with respect to the nature of law has depended upon the legal system which the particular jurist saw before him. The commonest fault in the jurist has been overambition to construct universals on the strength of what he has before him at one time in one system. ${ }^{50}$

Pound's comparative erudition, in short, sensitizes his analysis to the historical and geographical contingency of particular legal conceptions. Pound allows this awareness to reflect back on his analysis of American jurisprudence, resulting in his characterizing as "extreme" Gray's statement that, "It has been sometimes said that the law is composed of two parts - legislative law and judge-made law, but, in truth, all law is judge-made law."51 Pound also turns this awareness towards his comparative analyses, resulting in his refusal to obliterate Continental difference by analyzing civil law legal systems in terms of conceptions specific to the Anglo-American legal context of a particular era.

Pound therefore seeks to construct a methodology founded on relatively disinterested categories, such as his distinction between the "traditional" and "imperative" elements of a legal system. As described above, Pound argues that a given legal system is composed of "two elements, an enacted or imperative [legislative] and a traditional or habitual [judicial or juristic] element." 52 The production and maintenance of the fundamental distinction between these two cate-

48. Llewellyn, supra n. 8 , at 3 .

49. It should be noted that Pound explicitly associates this perspective with Karl Llewellyn and with Jerome Frank. 2 Jurisprudence at 83-84, quoting Llewellyn, supra n. 8, at 3, and Frank, Law and the Modern Mind 274 (1930). Despite the obvious lineage of the "what the courts/official do" perspective, Pound makes no such reference to Holmes. See id.

50. 2 Jurisprudence, at 75-76.

51. See id. at 75, n. 175, quoting John Chipman Gray, Nature and Sources of Law $\$ 276$ (1st ed. 1909).

52. 2 Jurisprudence, at 9. 
gories permits Pound to describe Continental European legal systems in terms that are relatively representative of those legal system's self-understanding. In particular, the use of these categories allows Pound to maintain and describe one of the most defining differences between common law and civil law systems, namely, the prototypically Continental refusal to collapse the distinction between lawmaking and judicial decision-making.

Pound therefore deploys the categories of the traditional and the imperative as a means to continue to differentiate between law-making and judicial decision-making, even in the face of the twentieth century American tendency to collapse that distinction almost as a matter of principle. His maintenance of the distinction does not, however, result in a static description of assorted legal systems. On the contrary, Pound stresses not only that at any given time, "[a] developed body of legal precepts is made of [the] two elements,"53 but also that " $[t]$ here is a constant shifting back and forth between these elements." 54

Pound's distinction between the traditional and the imperative (and other closely related distinctions) allows him to offer an active and structurally cyclical image of legal history. Thus, for example, when discussing the stage of "equity and natural law," Pound explains:

A stage of hard and fast rule is followed by one of wide discretion in which moral ideas, developed outside of the law, supplant or make over a large part of the legal system. In time, the doctrines, which have been brought into the law in this infusion of morality and morals, became thoroughly legalized. As we put it in Anglo-American law, a system of equity is worked out. But by the time this system has been completely achieved, the doctrines of equity have lost any distinctly equitable character. ${ }^{55}$

Pound's broad and disinterested categories therefore allow him to offer wide-ranging comparative and historical parallels, leading to a structural analysis of the cyclical rhythm of legal development. That is, Pound posits a constant shifting back and forth between what might be called the "yin and yang" within legal systems, a yin and yang that Pound terms either law and equity, ${ }^{56}$ or law and justice, ${ }^{57}$ or rules and discretion, ${ }^{58}$ or legality and morality, ${ }^{59}$ or the "stiffen-

53. Id. at 9 .

54. Id. at 10.

55. Id. at 419 .

56. Id. at 406-21, 2 Jurisprudence, at 378 .

57. 2 Jurisprudence, at 374-88.

58. 1 Jurisprudence, at 416-20.

59. Id. at 406-09. 
ing"/"fixing" and the "liberalizing" of a legal system and its precepts. ${ }^{60}$

The key to, and promise of, Pound's relatively non-parochial methodology is that it explicitly stresses the historical contingency of this ongoing oscillation between the imperative and traditional elements in assorted legal systems. Pound states:

Comparison of the development of juristic theory of law with the development of the forms of law and study of juristic theory of law in connection with the formulating agencies in law for the time being, show that there is no one absolute form of law ... or absolute type of lawmaking, but [rather] the juristic and the political agencies in lawmaking have each a place, greater or less according to the circumstances of time and country. ${ }^{61}$

Pound's methodology therefore turns out to be quite flexible. It is designed precisely to describe not only the similarities, but also the differences, between legal systems of various times and places. Although legal systems always appear to possess the yin and yang elements, the mix between the two constantly shifts. As Pound states: "In a sense all times are times of transition."62

By deploying non-common-law-centric categories, Pound's comparative work can therefore offer nuanced, sensitive, and historically and geographically contingent comparative analyses. As a result, Pound produces a far more satisfying portrayal of civil law legal systems than can be offered by an analysis that assumes that judicial decision-making means, almost by definition, judicial law-making.

Thus, for example, Pound describes in some detail that the French legal system has gone through a series of significant ideological changes over time. He argues, for example: "It was not until after the French code of 1804 that the imperative element got the upper hand [over the traditional element] in French juristic thinking. The development of French customary and Roman law which culminated in the writings of Pothier was still going on, and was going on under the influence of natural law."63 Pound therefore stresses that French law, although commonly associated with the dominance of the imperative legislature and its enacted codes, also draws its roots from the development of the traditional element. ${ }^{64}$ To demonstrate his point, Pound refers to, and quotes from, the work of none other than the

60. Id. at $406,417,421,2$ Jurisprudence, at 377,379 .

61. 2 Jurisprudence at 89-90 (emphasis added).

62. Id. at 377.

63. Id. at 51 (citations omitted).

64. See id. 
principle author of the French Civil Code, Pothier, who himself refers to principles of Roman law. 65

Pound's sensitivity to historical change leads him to describe a similar shift - this time in the opposite direction - in the French legal system of the twentieth century. In a remarkable passage, Pound explains:

France was the first country of Europe to reduce the whole of her law to legislative form. In consequence, after 1804 the formulas of French lawyers are characteristically imperative. They define droit as an aggregate of lois which are imperative in form and imposed by a lawmaking organ of politically organized society. This is what the law appeared to be in France after the codes. In the present century, jurists have been perceiving that the traditional element has played a very large, if not a controlling, part in the interpretation, application, and development of the civil code. Also the increasing importance of judicial decision as a form of law has been producing a significant body of law which is not legislative in origin or in form. But this traditional element was obscured for a long time by the form of French law. ${ }^{66}$

This passage demonstrates the fabulous sensitivity, subtlety and tact of Pound's comparative analysis. On the one hand, Pound begins his analysis with a statement that enacts the phenomenon it describes. He categorically states that "France was the first country of Europe to reduce the whole of her law to legislative form," thereby voicing the imperative ideology of the period he describes. On the other hand, this categorical statement undergoes a series of transformations. First, "the whole of [French] law" in the first sentence becomes "the formulas of French lawyers" in the second, which are then described in the third. Finally, in the fourth sentence - and the last to describe French law of the period -, Pound offers the brilliantly ambiguous sentence: "This is what the law appeared to be in France after the codes." What does Pound mean by this sentence? That French law not only was entirely imperative, but also appeared to be so? Or that French law only appeared to be entirely imperative, when in fact it was not? If the latter, why would French law not have been as imperative as it appeared to be? Would it be because, as Gray argues, "all law is judge-made law?"67 Or would it be because, as we have seen, Pound repeatedly argues that a legal system always possesses both the traditional and the imperative elements, even if one dominates the other at given times in given places? Or is it, perhaps, that Pound

65. See id., n. 111, quoting Pothier, Obligations, pt. 1, ch., 1, $\$ 1$ (Evans' trans. 1806, 2nd Am. ed. 1939).

66. Id. at 65-66 (citations omitted).

67. See id. at 75, n. 175 , quoting Gray, supra n. 51, at $\S 276$. 
is taking no position whatsoever on the issue of whether or not French law of the period actually was entirely imperative? In other words, is Pound simply stating that to the French of the early nineteenth century, "this is what the law appeared to be in France after the codes"?

I would argue that the first half of Pound's passage means all of these things. That is, I would argue that Pound's description encompasses each of the possible meanings because it accounts for the perspectives of different people in different times and in different places. Thus, Pound states that "this [entirely imperative character] is what the law appeared to be in France after the codes." ${ }^{\text {" }} 8$ In France at that time, the law appeared to be that way. But Pound's description also accounts for, or at least accommodates, the perspective of, for example, American common-lawyers. Thus one can easily argue that the French perspective of the time was faulty because it did not account for the existence of the traditional element, whether judicial or academic in origin. Pound, in other words, offers a scrupulously diplomatic description that enables each perspective to coexist with the others. In this passage, Pound never takes sides. He does not force one reading onto the described phenomenon or onto the reader.

In the second half of the passage, Pound continues in the same vein. He states, for example, that "[i]n the present century, jurists have been perceiving that the traditional element has played a very large, if not a controlling, part in the interpretation, application, and development of the civil code." Does Pound mean that French jurists have finally perceived what they should have perceived all along? Or that they are now perceiving the traditional element because this element has finally become important? Or is Pound talking not about French jurists, or not only about French jurists, but about all jurists, especially comparative law academics who may have misunderstood the French legal system all along? The passage sustains all of these readings.

Finally, Pound's description of French judicial decisions is nothing short of a masterpiece of nuance and tact. He states: "Also the increasing importance of judicial decision as a form of law has been producing a significant body of law which is not legislative in origin or in form. But this traditional element was obscured for a long time by the form of French law." To the common lawyer's eye, Pound appears to be stating that French judicial decisions do in fact constitute a veritable source of law. But to anyone familiar with French academic doctrine, Pound appears to be carefully explaining the nuanced French position on the authority of judicial decisions. Thus, although Pound notes that "the increasing importance of [French] judicial decision[s] as a form of law has been producing a significant body of law

68. Id. at 66 (emphasis added). 
which is not legislative," he makes sure not to state that French judicial decisions are a source of the law. He merely notes that the importance of the decisions "has been producing a significant body of law which is not legislative." 69

Since the turn of the century, most French academic doctrine has been built on this subtle distinction between judicial decisions as law and judicial decisions as merely productive of law. The dominant French position since Gény has been precisely that judicial decisions merely contribute to the formation of law by acting as an "initiator" of, or "propulsion device" for, true sources of the law, such as "custom." 70 Pound demonstrates his sensitivity to this civilian perspective not only in this passage, but also in a later section in which he discusses the six types of "sources of the law" "behind which the lawmaking and law administering authorities may put the power of the state."71 Pound states that "[a]djudication, giving rise to a custom or tradition of judicial action, as usage is a custom of popular action. In the civil law a settled course of decision of a question of law in a certain way became a form of law."72

Pound therefore refuses to impose the prototypically American common law perspective of Gray, Holmes and Llewellyn on his object of comparative analysis. He refuses to argue that French judicial decisions, even in the middle of the twentieth century, actually are law, an argument that would simply obliterate the primary locus of difference between French and American legal ideology. He offers instead an erudite explanation that respects the French perspective on French law and thus offers his readers a rich and fine-grained comparative description.

Roscoe Pound, in short, offers an extremely promising approach to comparative law. His cosmopolitan erudition gives him both a panoramic perspective on, and specific access to, foreign legal theory and substantive law. It also sensitizes him to the historical and geographic contingency of legal concepts and categories, resulting in a keen awareness of the dangers of adopting a comparative methodology founded on parochial perspectives. Pound therefore produces a methodology that depends on relatively disinterested, non-commonlaw-centric categories. On the basis of this methodology, Pound constructs a theory that depicts the history of western legal systems as structurally cyclical, but that also stresses the historical and geographic contingency of that cycle in any given legal system at any given time. Finally, Pound demonstrates the potential of his comparative historical methodology by deploying it in a sensitive, nuanced

69. See id. (emphasis added).

70. See Lasser, supra n. 5, at 1350-51, quoting François Gény, 2 Méthode D'interprétation et Sources en Droit Privé Positif 50-52 (2nd ed. 1919).

71. 3 Jurisprudence at 383 (emphasis added).

72. Id. at 385 . 
and suggestive fashion when he analyzes specific aspects of particular civilian legal systems. Read in a generous light, Pound's Jurisprudence therefore represents a treasure-trove for the contemporary American comparativist.

\section{The Severe Reading}

The generous reading outlined above is precisely that, generous. It must be understood, however, that Pound's Jurisprudence suffers from some debilitating faults. These faults, should the reader choose to stress them, can absorb and eventually overwhelm the generous reading altogether.

Pound's pedantic erudition represents his comparative methodology's most persistent, though least serious, problem. As Wigdor relates in his biography of Pound,

As a scholar, Pound's voracious appetite for evidence also held his insight in check, and his learning became more ponderous as his career progressed. "I think he believes," complained Harold Laski, "in the natural right of every German to be quoted." Felix Frankfurter expressed fatigue with "the accumulated logomachy of centuries. . . . Pound is too damned scholarly for me." . . . Laski's criticism was especially biting. If, in an essay on jurisprudence, "Pound found it necessary to say that the bathroom had made large developments in America he would put in references (a) to the Sanitary News, (b) to the Plumber's Journal and (c) to the Commerce Department's report on the increased manufacture of lead-less glaze together with a note to the effect that there was a Czech thesis on the sociological significance of the American bathroom which he had not seen."73

As the following passage on "psychological intuitionism" in sociological jurisprudence readily demonstrates, Laski's critique is to the point. Pound states:

PSYCHOLOGICAL INTUITIONISM is represented by Leo Petrazycki. His writings for the most part are accessible only in Russian or Polish. A few have been translated into German, and he was much discussed for a time. He gives us an intuitionist version of the psychological sociology of law. . . . But American juristic realists do not seem to have read him. ${ }^{74}$

73. Widgor, supra n. 1, at 285 (citations omitted).

74. 1 Jurisprudence at 343-44 (citations omitted). Although I have chosen to spare the reader Pound's list of citations, it is worth noting that Pound offers no less than seven of them, of which three are in German, one in English, and three in French. See id. at 343, n. 131. 
As this passage demonstrates, Pound is willing to make fantastically obscure references, and is then happy to criticize others (especially realists) who might not be able to do the same..$^{75}$ Furthermore, one cannot help but wonder about the quality of all of Pound's references, especially after one encounters a few along the lines of those we observed in the "Oriental" context. ${ }^{76}$

Far more problematic, however, is the crude model of legal evolution that permeates Pound's jurisprudence. The problem is not so much that Pound's analysis demonstrates a certain affiliation to turn of the century Darwinian or evolutionary theory, ${ }^{77}$ but that his evolutionary model is sufficiently crude and parochial that it forces his historical analysis of the world's legal systems into a single progress narrative whose end or telos turns out to be nothing but the common law judge.

For all of his varied and encyclopedic erudition, therefore, Pound offers a stunningly simple account of the development of legal systems over time. As we have already briefly seen, Pound claims that western legal history has progressed through a series of five to six "stages of development," beginning with the stage of "primitive law," ending with that of "the socialization of law," to a final stage, that of "A Law of the World."79

By attempting to structure several thousand years' worth of legal history into a mere five stages, Pound produces historical categories that are almost comically reductionist. Thus, for example, Pound explains the "primitive law" stage in the following terms: "In the beginnings of a legal order the idea is simply to keep the peace. At first the law attempted nothing more affirmatively than to regulate and provide a substitute for revenge." 80 In the next stage of development, that of the "strict law," "the chief end which the legal order seeks is certainty in the application of legal remedies." ${ }^{81}$ How probative can such an analysis actually be? For all of his cosmopolitan erudition, Pound arrives at little more than the platitudes one would expect from an attempt to summarize some two thousand years of legal history in a two by four inch chart. 82

Pound then compounds the failings of his analysis by superimposing a relentless progress narrative on his crudely structuralist history. Thus, for example, when Pound compares "the strict law with

75. But see supra n. 32 .

76. See supra text accompanying notes $40-44$.

77. For an excellent article on the relationship between legal theory and evolutionary theory, see Hovenkamp, "Evolutionary Models In Jurisprudence," 64 Tex. L. Rev. 645 (1985).

78. 1 Jurisprudence at 361.

79. Id. at 457 .

80. Id. at 370 .

81. Id. at 384.

82. See supra chart accompanying n. 20 . 
the prior stage of legal development," he states that "[t]he strict law has advanced from the idea of keeping the peace to the more general idea of security." 83 Similarly, "[t]he resource employed by primitive law is composition. The strict law has advanced to the idea of legal remedies;" 84 and "the maturity of law. . . is greatly in advance of the strict law. . because it insists not merely on equality of application of legal remedies but on equality of rights. . . ."85 In Pound's scheme, legal history "advances" from stage to stage in a forward march of progress.

Pound's legal history, furthermore, is patently monolithic and universalizing. As we have already seen, Pound offers a unified history of the development of western legal systems. His historical analysis proceeds by stages, making little or no effort to distinguish between the histories of Rome, France, Germany, England, and/or the United States. To the contrary, the whole point of his structural analysis is to subsume these specific histories into a single, universal history. He therefore peppers his historical narrative with explanations along the lines of, "The tendency the world over . . . is to . . ."86 Or he explains that recent American distrust of the judiciary is due in part to "universal" "causes which operate throughout the world."87 Combining this universalizing tendency with his crudely structural analysis and relentless progress narrative, Pound offers such painfully simple theories as the following:

The coming in of this idea is perhaps the most revolutionary change in legal history. But only the systems which, having achieved a strict law, went through this change and came to measure things by reason, instead of solely by rule and formula, have become laws of the world. 88

Having reached this level of vague platitudes, Pound's historical analysis suddenly offers not a single citation. ${ }^{89}$

The universalizing pretensions of his historical analysis surface most clearly when Pound turns his gaze toward the future. In the section tellingly entitled, "What of a Next Stage - A Law of the World?," Pound explicitly decries the fact that Anglo-American legal provincialism has delayed the adoption of universalizing theoretical perspectives. Thus, although " $[w]$ orking out a theory of the relation of local legislation and administration to universal principles of law for a unified world may become the compelling task of the jurists of to-

83. 1 Jurisprudence, at 405 (emphasis added).

84. Id. at 406 (emphasis added).

85. Id. at 423 (emphasis added).

86. Id. at $\mathbf{4 5 2}$.

87. 2 Jurisprudence, at 464.

88. 1 Jurisprudence, at 413.

89. See id. 
morrow,"90 "[i]nterest in universal ideas and ideals did not become general in our law schools until the present decade."11 American common law academics must partake of the universal forward march of legal evolution.

Most importantly, although perhaps not terribly surprisingly, the telos to Pound's crudely evolutionary progress narrative reveals itself to be quite clearly common-law-centric. The foreshadowing of Pound's judge-oriented, common-law-centric conclusions emerges in the very preface to his treatise. Pound argues:

It has seemed to me important also, now that comparative law is finding a place in legal education, to bring out that it is not simply a comparative cataloguing of rules in this lawmaking jurisdiction or that, but may show how, while the same problem of law and justice may often have received different answers from different legislators, yet principles, starting points for judicial reasoning, derived from experience of adjudication or doctrinal exposition, have been tending more and more toward a uniformity of law except where local geographical, ethnic or economic conditions require special rules. ${ }^{92}$

In this important passage, Pound summarizes and presents his comparative jurisprudential thesis. Pound recognizes that legislators have given different answers to legal questions in the past and may still be doing so to some extent in the present. But, frankly, the legislators' actions do not really matter. The key, in Pound's view, is that "principles," the "starting points for judicial reasoning," are becoming uniform regardless of legislative differences. Pound makes a polite gesture to the civilian professors by suggesting that not only judicial experience ("experience with adjudication") but also "doctrinal exposition" may help to derive such principles. But what matters in the end is what judges, not legislators, do.

As Pound looks to the possibility of a future "law of the world," he therefore immediately foregrounds the rising worldwide importance of the judicial role. Thus as soon as he refers to the "compelling task" of "[w] orking out a theory of the relation of local legislation and administration to universal principles of law for a unified world,"93 Pound notes: "It is significant that reliance upon judicial discovery of application of reason to experience is superseding the political idea of necessary exclusive legislative prescribing of rules. . . ."94 Pound presents the construction of a workable universal law as a judicial

90. Id. at 459 .

91. Id. at 457-58.

92. Id. at viii.

93. Id. at 459 .

94. Id. 
task. In support of this contention about the future, Pound therefore points to current/recent legal developments. He states:

The current revision of the French Civil Code omits the provisions forbidding ascertainment of the law by course of judicial decision, and all the recent codes provide for the materials and procedures by which the law is to be ascertained in the course of judicial decision. ${ }^{95}$

Even the civil law nations - and most importantly the French, the ideologues of the civil law - have come to acknowledge the importance of the judicial role in law-making. In Pound's teleological history, the role of the judge "is superseding" the notion of the legislative monopoly in lawmaking, thereby preparing the ground for a future universal law. ${ }^{96}$

It is not terribly important for our purposes that the French never did in fact revise their Civil Code as Pound apparently expected. Instead, the above passages demonstrate that, in the final analysis, Pound reveals himself to be not only resolutely in favor of common law notions of the judicial role, but also incapable of sustaining a perspective on the role of the civil law judge that respects the traditional civilian (and especially French) refusal to accept that judges make "law."97

In the third volume of Jurisprudence, in the chapter entitled "Sources and Forms of Law," Pound reveals most clearly his inability to shed his American common law perspective when analyzing civilian legal systems. Pound puts forth his analysis:

After the codes the theory was that the text of the code alone had authority and only the legislature could give an authoritative interpretation. ... Hence Continental writers have insisted that [academic] doctrine and [judicial] jurisprudence are not forms of law because, it was said, they did not furnish general binding rules, to be followed by any court in any case to which they were applicable, but each court was to be guided by them as and to the extent it saw fit in passing on a case not covered by the code. In truth, however, the courts do follow judicial decisions today very much as we adhere to precedents. It is said that single decisions have only persuasive authority, while a uniform course of decision is held theoretically to be equivalent to custom and have force as such and so to be a form of law. But single decisions are now cited and followed by the courts and by the text writers and the latter now cite and discuss not only decisions of the [French]

95. Id.

96. See id.

97. It may be indicative of Pound's common law perspective that he assumed that the French would in fact revise their code as he expected. 
Court of Cassation and Courts of Appeal but even those of courts of first instance. A like story may be told as to the course of judicial decision and even single decisions in Germany.

Application of the code provisions and development of them by analogical reasoning has commonly been called interpretation. It is not genuine interpretation, but is given the name in order to satisfy an idea that the code covers every possible case. . . 98

In this passage, Pound produces the prototypical American common law analysis of civilian, and especially French, theory and practice of the judicial role. Pound depicts the French/civilian perspective in patently dismissive terms by structuring the passage as a duet between two positions, only one of which has credence. First, Pound portrays the "Continental" position as theoretical ("After the codes the theory was. .."), doctrinaire ("Hence Continental writers have insisted. .."), and rhetorical/sophistic ("it was said. .."). Second, Pound responds to this Continental position with what appears to be the voice of reason ("In truth, however, ..."). Pound then continues with another round of the duet. He returns to the Continental position, immediately recognizable by its rhetorical leitmotif ("It is said. .."); and then responds to this position with a reality check ("But. . .").99

This structure prepares the ground for the passage's substantive argument. Quite simply, Pound argues that the Continental theory about judicial law-making does not comport with reality. Thus, the "theory" is that the Code alone has authority, and thus that judicial decisions are not a veritable "form" or source of law. In reality, however, or as Pound states, "in truth," "the courts do follow judicial decisions today very much as we adhere to precedents." Judicial decisions are therefore said to be engaged in mere interpretation of the code, when in fact this is mere sophistry designed "to satisfy an idea that the code covers every possible case. ..." Pound's conclusion appears to be quite clear: Whatever Continental legal systems may say, judicial decisions (and even academic doctrine) are in fact sources of Continental law. ${ }^{100}$

At the end of this section on "Forms [of law] in modern Roman law and under modern codes," i.e., on sources of the Civil Law, Pound states his position overtly. He declares:

For practical purposes the communis opinio doctorum, consensus of [academic] text writers, and usus fori, course of de-

98. 3 Jurisprudence, at 422-24 (citations omitted).

99. See id.

100. See id. at $422-24$. 
cision of the courts, have been forms of law. The former was dominant until recently. The latter is now superseding it. ${ }^{101}$

At this point in his analysis, Pound has succumbed to a truly American common lawyer's perspective. He has clearly aligned his analysis and understanding of Continental legal systems with the "In truth," "But," and "For practical purposes" position, thereby rejecting and dismissing the Continental "theory." Pound takes his observation that "the courts do follow judicial decisions very much as we adhere to precedent," and transforms it into the conclusion that the "course of decision of the courts" actually constitutes a source or "form of law." By offering this conclusion, Pound makes the typical common lawyer's reductive mistake of assuming that because Continental courts "follow" past decisions, that those past decisions therefore can be assimilated to common law precedents, thereby leading to the conclusion that Continental judicial decisions make law. ${ }^{102}$

This common law perspective on the civil law functions on the basis of assumptions that apply in the American legal context but may very well not apply, for example, in the French. Just because courts follow the prior decisions of other courts does not mean that the prior courts have "made law," any more than a Utah court's following of a New York decision means that the New York court has made Utah - or even New York - law. The key question is how one wishes to define "law." One might well be tempted to define law in the Gray/Holmes/Llewellyn fashion ("all law is judge-made law;"103 "what the courts do in fact;"104 what "officials do about disputes"105). But as Pound himself notes in a more lucid moment, "The commonest fault in the jurist has been overambition to construct universals on the strength of what he has before him at one time in one system."106

Just because the American common law tradition may have been premised on the judicial enunciation and development of law, and may have therefore tended to assume that judges make law, this does not mean that the same assumptions hold true elsewhere. To make this assumption about the judicial role and about its relation to the definition of "law" may well have been justified in the American context, and may well have had significant analytic and even critical bite at the particular historical moments in which this assumption was advanced and defended as a particular theory about law. But to take that theory, transform it into an assumption, and then use it uncritically as the prism through which to describe and analyze Continental

101. Id. at 426 (citations omitted).

102. Dawson and Merryman make functionally identical arguments. See Lasser, supra n. 5, at 1329-33.

103. 2 Jurisprudence, at 75 , n. 175 , quoting Gray, supra n. 51 , at $\S 276$.

104. Holmes, supra n. 8, at 460-61.

105. Llewellyn, supra n. 8, at 3 .

106. 2 Jurisprudence, at 76. 
legal theory and practice is to adopt a methodology that obliterates precisely the locus of the some of the most basic differences between American and Continental European legal ideologies. At that point, such a comparative methodology cannot describe the Continental position except as a projection of common law assumptions.

Once again the telos of Pound's evolutionary narrative in the Continental context therefore turns out to be judicial lawmaking. ${ }^{107}$ As Pound explains, judicial decisions are "now superseding" even academic doctrine as a source of law. ${ }^{108}$ Given Pound's position on the judicial role in constructing the future "law of the world," one cannot help but sense his approval of this development in Continental law.

In case one had the slightest residual doubt about Pound's common-law-centric perspective and allegiance, one need only turn to his assessment of the virtues of "judicial justice." Pound states:

Turning to the advantages of judicial justice, in the first place, with respect both to the law-declaring and the deciding function, it combines the possibilities of certainty and flexibility better than any other form of administering justice. It provides for certainty through the training of judges in logical development and systematic exposition of authoritative grounds of decision. It provides for growth by permitting a scientific testing of received premises with reference to concrete causes and correction of rules by extension or restriction through experience of their application and a gradual process of inclusion and exclusion upon rational principles. ${ }^{109}$

Pound, as this passage makes abundantly clear, makes no attempt to hide his canonical common lawyer's belief in the superiority of judgebased law. It is no accident that Pound ends "The Nature of Law" (Volume II of Jurisprudence) with the chapter "Judicial Justice," which offers the above elogy to judge-centered law. Pound's teleological narrative of comparative legal history leads to a very precise end: a universal law of the world, formulated and administered by the common law judge.

Finally, Pound's teleological narrative cannot be disassociated from his parochial jurisprudential ends. In particular, Pound's comparative historical analysis appears to be motivated by his personal crusades against "mechanical jurisprudence" on the one hand, and "realism" on the other.

Pound's most famous contribution to American jurisprudence was his attack on "mechanical jurisprudence." In his famous 1908 ar-

107. See 3 Jurisprudence, at 426.

108. See id.

109. 2 Jurisprudence 456. 
ticle, "Mechanical Jurisprudence,"110 Pound critiqued the deductive and abstract jurisprudence of conceptions. By the time Jurisprudence was published some fifty years later, Pound's critiques of mechanical jurisprudence appear to be less pressing. In particular, Pound's comparative legal history presents a progress narrative according to which mechanical jurisprudence emerges as an outdated nineteenth century phenomenon that has been overtaken and left behind by the passage of time and by the resulting "advances" in legal theory and practice. ${ }^{111}$ Pound's historical narrative places mechanical jurisprudence primarily in the "maturity of law" stage of legal development. ${ }^{112}$ As Pound's historical analysis posits that law has passed to the "socialization of law" stage of development, 113 "mechanical jurisprudence" is reduced to a souvenir of a bygone and surpassed era.

Pound's historical narrative nonetheless evinces a preoccupation with securing this anti-mechanical victory. In other words, Pound's teleological progress narrative serves to foreclose reversion to mechanical jurisprudence. The narrative advances this project first and foremost precisely by being a progress narrative. A return to mechanical jurisprudence would therefore be a return to a prior "stage of development." It would constitute, quite simply, a regression or reversion. Pound speaks of returns to prior stages of jurisprudence in precisely such unsavory terms. Thus, for example, he characterizes the rise in importance of administrative law as follows: "[W]e must see in the revival of executive justice one of those partial reversions to justice without law. . . ."114

Pound's teleological progress narrative therefore recognizes that periodic historical regressions can and do occur, but acts to prevent such "reversions" precisely by identifying them as running contrary to progress or "advancement." Thus, for example, Pound chides Justice Harlan's reasoning in Adair $v$. United States:

This artificial type of reasoning, on the basis of a theoretical abstract equality, ignoring the facts of the economic order, began to disappear from the books, in this particular connection, fifty years ago. It no longer needs to be refuted in spite of temporary recrudescence after the first World War. ${ }^{115}$

110. 8 Colum. L. Rev. 605 (1908).

111. See 2 Jurisprudence, at 455, 467-69.

112. See 3 Jurisprudence, at 507-09. On occasion, Pound makes passing statements that could suggest that "mechanical" decisions are also characteristic of the even less advanced "strict law" stage of legal development. See, e.g., 1 Jurisprudence, at 389 .

113. See 1 Jurisprudence, at 429-56.

114. 2 Jurisprudence, at 425 (emphasis added).

115. 1 Jurisprudence, at 534, citing, inter alia, Adair v. United States, 208 U.S. 161,175 (1908) (other citations omitted) (emphasis added). 
In Pound's analysis, therefore, a return to nineteenth century jurisprudence represents the outbreak of a disease that had been in remission. Pound again states:

No doubt the will-jurisprudence of the nineteenth century will hang on here and there for a long time to come, just as the contract jurisprudence of the eighteenth century has been known to darken counsel in out-of-the-way cases even in twentieth century courts. ${ }^{116}$

Pound's comparative history thus demonstrates the universal march forward towards progress, lest, to use Pound's own imagery, the backward forces of darkness (i.e., nineteenth century mechanical jurisprudence) be allowed to return.

At the same time, Pound's comparative analysis explicitly warns against steering from the Scylla of mechanical jurisprudence into the Charybdis of realism. Pound therefore argues:

On the whole, the common-law canons of interpretation are grounded in experience developed by reason and tend to a better administration of justice than leaving interpretation in each case to feelings of policy on the part of the tribunal, which may or may not be those of the legislators. If the canons were sometimes applied too rigidly in the last century, it was rather because of a tendency to mechanical handling of all law at that time than because of any intrinsic unsuitableness of the canons themselves. ${ }^{117}$

In this passage, Pound reveals the trajectory of his teleological narrative and thus the parameters of his historical analysis. From the mechanical approach of the nineteenth century, jurisprudence must not resort to arbitrary "feelings of policy," but should embrace the common law's reasoned and principled treatment of judicial experience. Interpretation should therefore not mean "affixing to a legal formula any meaning which is required to bring about a result dictated by convenience or expedience or individually conceived policy."118 Interpretation must not become "spurious," for "this type of spurious interpretation aggravates the tendencies on which the extreme realists have been putting so much stress and re-introduces an arbitrary element into the administration of justice."119 The telos of Pound's narrative, therefore, must not be the arbitrary consideration of policy urged by the "extreme realists."

Roscoe Pound, in short, deploys his significant erudition not in the service of fine-grained and culturally sensitive comparative analysis, but rather in the service of the pedantic demonstration of a

116. Id. at $\mathbf{5 3 8}$ (emphasis added).

117. 3 Jurisprudence, at 506.

118. Id. at 488.

119. Id. at 489 . 
crude model of legal evolution. Pound proposes a unified and universalizing version of comparative legal history that presents all Western legal history as advancing through a handful of "stages of development." Furthermore, not only does his progress narrative reveal itself to be teleological, but its telos turns out to be nothing other than the American common law judicial system. Pound therefore constructs a comparative legal history whose task is to ensure the obsolescence of mechanical jurisprudence while avoiding the policy analysis of the "extreme realists," thereby arriving at the ultimate goal, a "law of the world" enunciated and administered by the common law judge. Forced into this common-law-centric perspective, Pound's comparative analyses cannot help but efface the differences between common law and civil law legality.

\section{Synthetic Conclusions}

The "generous" and "severe" readings offered above suggest several conclusions. The first is that although Pound's treatise provides more than enough evidence to support one or the other reading, neither of the two readings offers an accurate depiction or correct interpretation of his work. The point of presenting the two readings has been to suggest that interpreting Pound's treatise requires that one take account of both readings.

I would like to stress, however, that I am not suggesting that the two readings be reconciled. In many ways, the least satisfying response to the readings would be to "split the difference" between them, to offer a single reading "somewhere in between the two extremes." The comparative methodology that Pound deploys in his treatise is not somewhere in between being sensitive to cultural difference and being destructive of it. It is both. At times, as stressed in the "generous reading," Pound makes a point of the historical, geographical and cultural contingency of legal concepts and categories, resulting in a keen awareness of the dangers of adopting a comparative methodology founded on parochial perspectives. At other times, as stressed in the "severe reading," Pound utterly fails to heed his own warnings; he offers instead a stunningly rigid and universalizing progress narrative that measures legal "advancement" in terms of his parochial commitment to the heroic common law judge, thereby annihilating most of what is distinctive about non-common law systems. To collapse these two aspects of Pound's treatise into one by, in essence, producing an average between them would be artificial, i.e., synthetic.

There are, however, many different ways to put together the "generous" and "severe" readings. It is by no means impossible to propose an integrated interpretation, for example, of Pound's comparative legal history. As we have seen, Pound offers two different 
histories. According to the first, Western legal systems tend to cycle or oscillate - in a historically, geographically and culturally contingent manner - between their "traditional" and "imperative" elements. According to the second, however, Western legal systems progress through a series of "stages of development" towards a unified "law of the world." The clever reader would have little difficulty integrating these two histories by, for example, arguing that Pound offers a complex history that accounts for culturally contingent cycling between elements within a generally linear progression. Thus, depending on the time and place, the development of one legal system's precepts may be shifting more towards legislation and away from judicial norms, while that of another might be shifting more towards academic doctrine; but in both cases, despite their particularities, the general historical trend will be to progress through a series of discrete stages of development eventually leading to a unified law of the world. This integrated interpretation allows for synchronic contingency (at a given place and time, the particular mix of traditional and imperative elements is historically and culturally contingent) while stressing diachronic structure (over time, the legal system progresses through a specific series of stages).

This integrating solution may well offer an elegant solution to Pound's double history. But does its integration, its synthesis, propose the most engaging, or challenging, or productive, or even representative interpretation of Pound's historical methodologies? Pound's treatise actually offers a more disjointed and unreconciled methodology than this synthesizing interpretation would suggest. By limiting the element of contingency in Pound's analysis to a mere element of play within an otherwise unified structure of historical progression, this reading minimizes and sublimates the potentially remarkable sensitivity of Pound's comparative methodology.

Pound's Jurisprudence contains and reveals widely divergent comparative impulses. On the one hand, it evinces an awareness of cultural difference, and its analysis therefore seeks to stress and maintain that difference. In this context, Pound offers his warning against the perils of universalism and of parochial perspectives. On the other hand, Pound's treatise also demonstrates an impulse towards integration, and its analysis therefore seeks to stress similarities and downplay cultural difference. In this context, Pound dismisses, for example, the classic French theory about the sources of the law and instead describes the lawmaking power of French judicial decisions in terms far more familiar to the American common lawyer. Pound rarely, if ever, offers an overarching theory that transcends and thus reconciles such disparate impulses.

At other points in his treatise, however, Pound does in fact offer specific analyses that synthesize the difference and similarity im- 
pulses. In the following passage, for example, Pound stresses both the similarities and differences between civil and common law approaches to legislation and judicial decisions:

In the common law, . . a statute furnishes a rule for the cases within its purview, but not a basis for analogical reasoning. For that we look to experience of the administration of justice in the reported decisions of the courts. In the civil law, ... the technique in this respect is wholly different. The civilian reasons by analogy from legislative precepts and regards a fixed course of judicial decision on some point as establishing that precise point, but not as providing a principle - an authoritative starting point for legal reasoning. ${ }^{120}$

After explaining that in the common law, judicial decisions serve as the basis for analogical reasoning, Pound continues:

Again, although the courts in continental Europe have come to treat the course of judicial decision as a form of the law, and single decisions of the highest court of review are now cited by commentators as indicating such a course, there is still a difference between our technique of precedents and that which has been developing in the civil-law world. ${ }^{121}$

Finally, Pound explicitly describes the similarities:

[The common-law] principle of tort liability as a corollary of fault or the principle that no one is to be enriched unjustly at another's expense. . . are authoritative premises for judicial reasoning. We use them as the civilian uses a text of code or a text of the Digest. The circumstance that the common law of continental Europe is in form legislation of an emperor while our common law is in form a body of reported decisions, obscures the identity of our analogical reasoning from common-law principles with the civilian's interpretation of a century-old code. ${ }^{122}$

In a passage such as this, Pound produces an analysis that synthesizes his description of common law/civil law difference and similarity. In both systems, legal reasoning proceeds by analogical reasoning from legal principles. Due to "circumstance," however, the two systems generate their legal principles from different sources, the judicial and the legislative. The two systems are therefore similar and yet different; different and yet the same. The synthesis emerges quietly in the last sentence quoted above: Pound refers to "the common law of continental Europe."

120. 2 Jurisprudence at 107-08 (emphasis added) (citations omitted).

121. Id. at 110 (emphasis added) (citations omitted).

122. Id. at 111 (emphasis added). 
Roscoe Pound's Jurisprudence, in short, proceeds on the basis of divergent comparative impulses, offers divergent comparative analyses, and sustains divergent readings. At times, Pound warns against parochially constructed universals, and therefore constructs a methodology that deploys relatively disinterested, non-common-law-centric categories. When he does, he produces nuanced and sensitive descriptions of civil law consciousness and practice. At other times, Pound refuses to heed his own warnings, and therefore proceeds on the basis of prototypically judge-centered common law assumptions. When he does, he produces comparative analyses that are functionally indistinguishable from the post-realist analyses of, for example, John Dawson and John Merryman.

When Pound is at his best, ${ }^{123}$ however, the status of his comparisons is held in suspension. At such moments, it is not clear whether he is offering a description or an analysis of the object of comparison. It is not clear whether he is writing from the perspective of the object of analysis or from that of the observer. At such moments, the status of his text is in flux and in doubt, for Pound imposes neither perspective on his reader. At this point, it is Pound's text that becomes the object of analysis, and the reader that is suddenly placed on the comparative spot.

Searching for alternatives to comparative approaches that efface civilian differences by describing them in parochially American realist terms, I would therefore tend to stress and promote Pound's more disinterested categories and the culturally sensitive analyses they enable. But only a small change in project would be necessary to underline Pound's common-law-centric tendencies instead, and thereby collapse his work into that of Dawson and Merryman.

Either reading of Pound would be legitimate and justifiable. More than enough evidence can be marshaled to support either one. As when approaching any object of analysis or comparison, the student must make a choice of how to construct the object: Which of its elements should be understood, and thus described, as "facets," which should be stressed and valorized, and what should one then make out of them?

In a feeble attempt to emulate his most enviable rhetorical strength, I leave my reading(s) of Pound in suspension. ... Coming to grips with his comparative thought turns out, in the end, to resemble coming to grips with the thought of foreign jurists. Pound's comparativism is complex and contradictory. It can be subtle; it can be crude. It can offer a certain access and sensitivity to foreign mindsets and understandings; it can offer access to little more than Pound's own worldview. In an attempt not to reproduce Pound's inevitable fail-

123. See, e.g., supra text accompanying n. 66 . 
ings, that is, in a perhaps futile attempt to minimize the extent to which I must impose my own thought on Pound's, I have tried to experiment with ways of accessing, reading and re-presenting his thought by suspending - if only briefly and imperfectly - my own interpretive "judgment." This suspension, I hope, might induce or at least permit a certain sensitivity to Pound, to the objects of his analysis, and to the reader. 